www.czasopisma.marszalek.com.pl/pl/10-15804/npw

Pawet NEUMANN-KarPińSKI

Uniwersytet Szczeciński

ORCID: https://orcid.org/0000-0001-7776-6563

\title{
Wojna w Donbasie - przyczynek do rozważań nad niedopowiedzeniami teorii wojny sprawiedliwej'
}

\section{War in Donbas - considerations on the understatements of the just war theory}

\section{Abstract}

The following article covers the analysis of the War in Donbas from the perspective of the "traditional concept of a just war" (as interpreted by Michael Walzer). The main axis of the analysis is determined by the issue of the possibility of third countries intervening in armed conflicts concerning the specific case of the War in Donbas. The text indicates the key factors that make it impossible to develop a conflict in eastern Ukraine according to traditional just war theories, such as the pursuit of incomplete secession of pro-Russian separatists, the status of the Russian Federation as an unofficial participant in the conflict, and the problem of the "reality" of the separatist intention itself. Therefore, the main problem of this work is the interpretation of Russian actions from the perspective of the principle of non-intervention, and the attitude of other third countries and their right to (not) intervene in this conflict, and its conclusion - in the author's opinion - indicates

1 Niniejszy artykuł nie powstałby bez wsparcia prof. UJ dr. hab. Tomasza Żuradzkiego, którego kurs „Etyka wojny” i odbywające się w jego trakcie dyskusje stanowiły podstawę merytoryczną i inspirację dla powstania tego tekstu. 
the need to update the theory of just war, in a way that would clearly indicate the proper conduct in the event of secession in favour of the existing state.

Keywords: War in Donbas, just war, just war theory, secession, military interventions

\section{Война на Донбассе - размышления о недосказанном на тему теории справедливой войны}

\section{Аннотация}

В данной статье проводится анализ войны в Донбассе с точки зрения «традиционной концепции справедливой войны» (по М. Вальцеру). Главной осью исследования является вопрос возможного вмешательства третьих сторон в вооруженные конфликты, в данном случае относительно войны в Донбассе. В тексте указаны ключевые факторы, которые не позволяют рассматривать конфликт на востоке Украины с помощью традиционных теорий «справедливой войны», в частности: стремление пророссийских сепаратистов к неполной сецессии, статус Российской Федерации как неофициального участника данного конфликта или проблема «реальности» самого сепаратистского намерения. В связи с вышесказанным главной проблемой статьи является интерпретация действий России с перспективы принципа «невмешательства», а также отношение других государств и их право на (не)интервенцию в этот конфликт, разрешение которого - по мнению автора указывает на необходимость актуализации теории «справедливой войны», чтобы она ясно показывала, какими должны быть правильные действия в случае сецессии в пользу существующего государства.

Ключевье слова: война на Донбассе, справедливая война, теория справедливой войны, выход из состава государства, военное вмешательство

Nie będziemy tutaj wygłaszać długich i nie wzbudzających wiary przemówień ani opowiadać pięknie o tym, że panowanie słusznie nam się należy, (...) albo o tym, że zaatakowaliśmy was, ponieważ nas skrzywdziliście. (...) Przecież jak wy tak i my wiemy doskonale, że sprawiedliwość w ludzkich stosunkach jest tylko wtedy momentem rozstrzygającym, jeśli po obu stronach równe siły mogą ją zagwarantować; jeśli zaś idzie o zakres możliwości, to silniejsi osiągają swe cele, a słabsi ustępują

Fragment „Dialogu Melijskiego”, jednego z najstarszych rozważań nad ideą ,wojny sprawiedliwej” (Tukidydes, 1988). 


\section{Wstęp}

T onflikt określany jako „wojna w Donbasie” rozpoczął się w marcu 2014 - roku, kiedy po rewolucji Euromajdanu i obaleniu rządów prezydenta Wiktora Janukowycza na przełomie 2013 i 2014 roku na Ukrainie zaczęły się prorosyjskie zamieszki i demonstracje (Kushch, 2014). Mieszkańcy niektórych ukraińskich terenów zadeklarowali wówczas chęć odłączenia się od Ukrainy, jednak nie w celu utworzenia niezależnych państw, ale dołączenia do Federacji Rosyjskiej. Tak było w przypadku Republiki Krymskiej, która 16 marca 2014 roku przeprowadziła - nieuznane przez ONZ - referendum niepodległościowe (Harding, Walker, 2014), a dwa dni później opowiedziała się za przyłączeniem do Federacji Rosyjskiej (Wirtualna Polska, 2014). Choć w oczach wielu państw działania te były bezprawne, aneksja Krymu przez Rosję nie wiązała się z otwartym, długotrwałym konfliktem zbrojnym, w który przerodziły się separatystyczne działania na wschodzie Ukrainy.

Przedmiotem niniejszej pracy jest analiza wojny w Donbasie z perspektywy „tradycyjnej koncepcji wojny sprawiedliwej”, prezentowanej przez Michaela Walzera (2010). Główną oś analizy wyznacza zagadnienie możliwości interweniowania państw trzecich w konflikty zbrojne, w odniesieniu do specyficznego przypadku wojny w Donbasie. Zagadnienie to wydaje się szczególnie istotne z uwagi na trzy czynniki: (1) fakt, że separatyści dążą nie do zupełnej secesji, ale do przyłączenia ich terenów do państwa trzeciego - Federacji Rosyjskiej, (2) która od pierwszych dni konfliktu udziela separatystom wsparcia, a także (3) jest przynajmniej pośrednio odpowiedzialna za wybuch konfliktu z uwagi na udział rosyjskich służb w szerzeniu nastrojów separatystycznych (Interfax-Ukraine, 2014). W związku z tym główny problem niniejszej pracy stanowi interpretacja rosyjskich działań w kontekście prawa państw do interweniowania w konflikty. Dodatkowo należy zadać pytanie o postawę innych państw trzecich i ich prawo do (nie)interwencji.

\section{Przebieg wojny w Donbasie i udział Federacji Rosyjskiej w konflikcie}

Aby adekwatnie określić charakter wojny w Donbasie i działania zaangażowanych w nią stron, konieczne jest zrekonstruowanie przebiegu 
kluczowych wydarzeń tego konfliktu. Rozpoczął się on w marcu 2014 roku od prorosyjskich, antyrządowych protestów, które eskalowały do otwartego konfliktu zbrojnego między siłami rządowymi Ukrainy a separatystami samozwańczych Republik Ludowych - Ługańskiej (ŁRL) i Donieckiej (DRL) (Grytsenko, 2014).

W sierpniu 2014 roku po raz pierwszy to, co Rosjanie określali mianem „konwoju humanitarnego”, a co w rzeczywistości było dostawą rosyjskiego wsparcia wojskowego, przekroczyło granicę bez zezwolenia ze strony Ukrainy. Wydarzenie to o kilka dni poprzedził dokonany z terytorium rosyjskiego ostrzał artyleryjski pozycji ukraińskich sił rządowych (BBC, 2014a; Gordon, 2014). Szef Sił Zbrojnych Ukrainy mówił wówczas o bezpośredniej inwazji ze strony Federacji Rosyjskiej (Zinets, Madorsky, 2014), zaś inni przedstawiciele Ukrainy i państw zachodnich określili te działania mianem „skrytej inwazji” (Kramer, Gordon, 2014).We wrześniu 2014 roku podpisano pierwsze zawieszenie broni między Ukrainą, ŁRL i DRL, a także Federacją Rosyjską (BBC, 2014b), jednak go nie przestrzegano i ostatecznie zakończono w styczniu 2015 roku. W lutym 2015 roku zawarto kolejne zawieszenie broni - ponownie z uwzględnieniem Rosji na równi z pozostałymi stronami konfliktu - i od tego czasu konflikt przeszedł w stan „zamrożenia” (Tsvetkova, 2015), choć na spornym obszarze cały czas prowadzone są walki².

Opinia międzynarodowa jest przekonana o udziale Federacji Rosyjskiej w konflikcie. Od samego jego początku Rosja oskarżana jest o udział w wydarzeniach na Ukrainie, w tym o zainicjowanie prorosyjskich rozruchów. Władze rosyjskie odpierają jednak te zarzuty (TASS, 2014), a wszystkie transporty na terytorium Ukrainy określają mianem konwojów humanitarnych.

Mimo to istnieją liczne dowody na rosyjskie wsparcie separatystów, w tym dostawy zaopatrzenia i sprzętu wojskowego (Grove, Strobel, 2014), a także na udział rosyjskich żołnierzy w walkach (BBC, 2014c; Borger, 2015; Sutyagin, 2015). W grudniu 2015 roku sam prezydent Władimir Putin przyznał, że możliwa jest obecność rosyjskich sił specjalnych wykonujących cele militarne na terenie Ukrainy, jednak zaznaczył, że nie jest to równoznaczne z obecnością żołnierzy regularnej armii (Tsvetkova, Osborn, 2015). Ostatecznie

2 Pomimo kolejnych prób zawieszenia broni wciąż prowadzone są działania zbrojne, które wiążą się z kolejnymi ofiarami. 
w 2018 roku drony Organizacji Bezpieczeństwa i Współpracy w Europie nagrały konwoje przekraczające granice między Federacją Rosyjską a Ukrainą oraz rosyjskie zaawansowane systemy wojny elektronicznej na terytorium separatystów (RFE/RL, 2018), co w debacie na temat rosyjskiego udziału w konflikcie wskazuje się jako ostateczny dowód militarnego zaangażowania Rosjan.

Warto jednak zaznaczyć, że choć udział Rosji w konflikt w Donbasie można uznać za dowiedziony, Federacja Rosyjska nie wypowiedziała otwartej wojny, ani nie przyznaje się do wspierania separatystów. Podjęła ona liczne działania, które wpłynęły na przebieg tego konfliktu, a być może nawet można mówić o odpowiedzialności za samo zaistnienie wojny w Donbasie.

\section{Teorie wojny sprawiedliwej i dopuszczalność interwencji Federacji Rosyjskiej}

Aby ocenić moralną dopuszczalność działań Federacji Rosyjskiej, należy najpierw określić czym jest wojna w Donbasie. Próby takiej klasyfikacji można dokonać w oparciu o tradycyjne teorie wojny sprawiedliwej zaprezentowane m.in. w Wojnach sprawiedliwych i niesprawiedliwych Michaela Walzera (2010, s. 147-176). Na ich podstawie omawiany konflikt uznać można za wojnę domową lub secesję, czyli działania zbrojne będące wyrazem samostanowienia - „prawa narodu do wybicia się na wolność o własnych siłach” Walzer, (2010, s. 149). Jednocześnie kategoria wojny domowej wiąże się z działaniami zmierzającymi do zmian w skali całego kraju, a prorosyjscy separatyści dążą jedynie do zmian na wydzielonym obszarze, który chcą przyłączyć do Federacji Rosyjskiej. Wojna w Donbasie jest zatem przykładem secesji, ale również nie takiej, na jakiej Walzer się koncentruje w swoim tekście. Nie skupia się bowiem na walce o niepodległe państwo narodowe, które przed rozpoczęciem konfliktu nie istnieje (2010, s. 91-95), ale jest przykładem secesji nakierowanej na przyłączenie terenów jednego państwa do innego, już istniejącego. Nazwę ten typ konfliktu secesją na rzecz istniejacego państwa (SIP), w odróżnieniu od secesji na rzecz nowego państwa (SNP), opisanej dokładniej przez Walzera. SIP, z uwagi na inny od SNP cel, wydaje się także różnić tym, kogo uznać należy za stronę konfliktu. Należy mianowicie 
rozpatrzyć, kiedy państwo, do którego chcą przyłączyć się separatyści, może być traktowane jak strona konfliktu.

Odpowiedź na pytanie o możliwą partycypację Federacji Rosyjskiej wydaje się szczególnie istotna w kontekście przywołanego przez Walzera wykładu M. Bernarda „On the Principle of Non-intervention”, w którym zaznacza, że jeżeli interwencja zewnętrzna jest kluczem do osiągnięcia zwycięstwa przez jedną stronę, to daje je tej, która nie zdołałaby osiągnąć zwycięstwa sama, a więc nie ma realnego uprawnienia do niego (Walzer, 2010, s. 96-97). Jeżeli więc Rosja nie byłaby stroną, to jej działania odbierałyby separatystom legitymację do odłączenia się od Ukrainy. Gdyby zaś była, nie mówilibyśmy o secesji, ale raczej o agresji państwa bez wypowiedzenia wojny. Dla rozstrzygnięcia tego zagadnienia konieczne jest zatem określenie, kim jest strona walcząca, czyli prorosyjscy separatyści.

Na wstępie warto jednak zaznaczyć, że problematyczna dla ujęcia w jakiekolwiek ramy pojęciowe jest działalność samych separatystów. Christopher J. Finlay, rozpatrując walkę organizacji niebędących państwami, zakłada, że każda taka walka jest próbą obrony obywateli, czyli jednostek stanowiących członków tej grupy, to znaczy jest pomocą w ich obronie własnej (2015, s. 157-159). Finlay wskazuje tu na warunek istnienia „właściwej władzy”, tj. związku politycznych organizacji niepaństwowych z jednostkami, których praw bronią i w imieniu których domagają się działania. Jest to warunek konieczny dla uznania zasadności zbrojnego oporu przeciwko uciskowi. Autor ten twierdzi, że uzasadnienie dla właściwej władzy organizacji opiera na sytuacji, w której znajduje się społeczność: na konieczności obrony własnej i pomocy osób trzecich w obronie własnej jednostek (Finlay, 2015, s. 158). Organizacje niepaństwowe muszą bowiem uzasadnić swoje użycie przemocy obroną jednostek przed indywidualną przemocą ${ }^{3}$.

Finlay wskazuje, że dla uzasadnienia tej pomocy potrzeba odpowiedniej relacji między ofiarą agresji a tym, kto jej pomaga, choć jak twierdzi, można też argumentować, że obowiązek pomagania przez niektóre zbrojne grupy oporu tym, którzy są atakowani, wypływa z ogólnego obowiązku sprawiedliwości. Wskazuje na trzy typy relacji między ofiarą a pomagającym: naturalna,

3 Finlay podaje przykład IRA, która argumentowała, że jej działania nakierowane są na obronę katolików w Północnej Irlandii (s. 159). 
„ratunek” oraz autoryzacja (autorska koncepcja Finlaya), czyli świadoma zgoda ofiary na udzielenie pomocy. Warunkiem koniecznym dla powołania się na autoryzację jest możliwości dokonywania deliberacji i komunikacji przez ofiarę - ratunek jest bowiem zarezerwowany dla osób niemogących zakomunikować swojej woli odnośnie do pomocy (Finlay, 2015, s. 160-163). Celem autoryzacji jest nie tylko sama pomoc ofierze przemocy, ale również poszanowanie wartości, którym hołduje $e^{4}$.

Wydaje się, że z uwagi na separatystyczne nastroje na obszarze, którego dotyczy konflikt w Donbasie, można mówić o pewnej autoryzacji udzielonej separatystom. Jednak, jak wskazał Finlay, sama ,zgoda” obywateli na działania zbrojne nie jest wystarczająca - potrzeba także przemocy i zagrożenia, na które te działania odpowiadają. Nie można jednoznacznie ocenić, czy prorosyjscy separatyści spełniają ten warunek: ich działania zbrojne rozpoczęły się, według ukraińskich relacji, w konsekwencji walk między demonstrantami wspieranymi przez rosyjskie służby specjalne (TVN24, 2014) a służbami policyjnymi i antyterrorystycznymi Ukrainy. Wydaje się, że jeżeli byłby to atak na demonstrantów chcących zorganizować pokojowy plebiscyt niepodległościowy, to zorganizowanie się w zbrojną grupę chroniącą obywateli byłoby uzasadnione. Nie jest jednak jasne, czy obecność rosyjskich służb, lub nawet samo podniecanie przez Federację Rosyjską nastrojów separatystycznych, pozbawia separatystów autoryzacji: wydaje się uzasadnione argumentowanie, że przez te czynniki działania separatystów nie spełniają przesłanki świadomej zgody, a także sugerują, że za inicjacją przemocy mogły stać prowokacje rosyjskich służb.

Można w tej sytuacji zapytać, czy rosyjska dezinformacja i propaganda wzbudzająca nastroje separatystyczne nie odbierają legitymizacji wyrazowi samostanowienia separatystów, którzy mogą - właśnie na podstawie tej propagandy - szczerze wierzyć, że, walcząc o secesję od Ukrainy na rzecz podległości Federacji Rosyjskiej, walczą o swoje bezpieczeństwo. Ponadto można zapytać, czy jeżeli ta secesja jest w głównej mierze wynikiem manipulacji ze strony Rosji, to czy nadal jest to secesja, czy też należy mówić już

4 Finlay argumentuje tu, że mogą być takie sytuacje, w których ofiara może odmówić pomocy, na przykład gdy jest pacyfistą lub hołduje innej ideologii potępiającej przemoc (s. 166). 
o agresji ze strony Rosji, zapoczątkowanej nie przez ofensywę militarną, ale propagandową?

Także Cécile Fabre, omawiając zagadnienie secesji, wskazuje, że kluczową przesłanką jest zgoda ludności zamieszkującej dane tereny, a separatyści tracą legitymizację do odłączenia terytorium od danego państwa, jeżeli czynią to z pogwałceniem sprawiedliwości, na przykład przez wykorzystanie przemocy lub przewagi liczebnej (2016, s. 133). Wydaje się, że można powołać się na to zastrzeżenie Fabre'a i wskazać, że mieszkańcy tych terytoriów nie byli jednomyślni co do secesji, a początkowe starcia odbywały się między demonstrantami strony prorosyjskiej i proukraińskiej, a także należy zaznaczyć, że prorosyjscy demonstranci siłą musieli przejąć między innymi budynki administracji publicznej i służb policyjnych (D’Agata, 2014).Z drugiej strony, można bronić separatystów argumentując, że w takich sytuacjach nie jest możliwe osiągnięcie zupełnej jednomyślności, przez co o losie wszystkich musi zadecydować większość, a liczba demonstrantów i ich siła, oraz fakt, że dołączali do nich także przedstawiciele służb, tacy jak żołnierze i milicjanci (Gazeta.pl, 2014), świadczyła o ich legitymacji do reprezentowania ogółu.

Ustalenie, czym jest wojna w Donbasie, nie jest zatem łatwe i być może dotychczasowe informacje nie pozwalają na jednoznaczną interpretację wydarzeń - wydaje się, że w większym stopniu z uwagi na charakter separatystów niż samą interwencję Federacji Rosyjskiej. Nie mogąc zaś ostatecznie ustalić, czy są oni stroną zmanipulowaną, czy „podstawioną” przez Rosjan, nie można też określić charakteru Rosji jako siły interweniującej. Jednocześnie absurdalną wydaje się propozycja odmówienia separatystom prawa do samostanowienia $\mathrm{z}$ uwagi na to, że zostali zmanipulowani i posiadają „błędne przekonania”, a ponadto wydaje się, że nawet manipulacja ze strony Rosji nie jest wystarczającym powodem do uznania ich za niesprawiedliwie walczących (MacMahan, 2009, s. 118).

\section{Niejawny konflikt jako wyzwanie dla teorii wojny sprawiedliwej}

Wojna w Donbasie nie odpowiada zatem standardom wyznaczanym przez tradycyjne koncepcje wojny sprawiedliwej i właśnie $z$ tego powodu warto rozważyć ją w szerszym kontekście. Ukraina jest członkiem ONZ, ale nie Unii Europejskiej ani NATO, choć jest partnerem Paktu Północnoatlantyckiego 
(Kernot, 2015, s. 135). Mimo to można się spodziewać, że w wypadku wypowiedzenia przez Federację Rosyjską otwartej wojny państwa zachodnie w pewnym stopniu ruszyłyby z pomocą Ukrainie. Gdyby bowiem takie ryzyko nie istniało, to domniemywać można, że nie byłoby powodów, dla których Federacja Rosyjska miałaby się powstrzymywać przed oficjalnym opowiedzeniem się po stronie separatystów, którzy sami deklarują chęć dołączenia do niej. Wydaje się zatem, że ów stan „niejawnej wojny”, nie ulegnie zmianie do momentu ostatecznego zakończenia tego konfliktu.

Sytuacja ta, choć specyficzna i nieodpowiadająca kryteriom podanym przez Walzera, nie jest pierwszą w historii. W 2008 roku podobnie przebiegała wojna w Osetii Południowej: działania zbrojne również poprzedzone były przez szerzenie nastrojów separatystycznych, w wyniku których mieszkańcy Abchazji i Osetii Południowej ogłosili secesję od Gruzji, dzięki której tereny te miały, ogłosiwszy niepodległość, przyłączyć się do Federacji Rosyjskiej. Wówczas Rosjanie otwarcie wkroczyli na terytorium podległe Gruzji argumentując, że dokonują interwencji w celu obrony swoich obywateli przed atakiem Gruzinów na ludność zamieszkującą Osetię. Konflikt zakończony został po pięciu dniach, a Rosja do dziś sprawuje kontrolę nad terytorium Osetii Południowej i Abchazji (North, 2015), mimo iż Gruzja i NATO nie uznają jej zwierzchnictwa na tych ziemiach. Dziś wskazuje się na to, że działania Federacji Rosyjskiej odbyły się z pogwałceniem postanowień Wspólnoty Niepodległych Państw (WNP) oraz Traktatu Pokojowego z Sochi, nie odpowiadały standardom operacji „sił pokojowych”, nie miały legitymizacji ze strony ONZ, WNP ani żadnej innej organizacji międzynarodowej do podjęcia się „egzekwowania pokoju” na terenie Gruzji, a także były sprzeczne z wewnętrznym prawem rosyjskim (Laaneots, Ühendatud, 2016, s. 94). Dodatkowo działania te doprowadziły do pogorszenia się relacji Federacji Rosyjskiej z „zachodem”, zwiększeniem czujności organizacji międzynarodowych oraz państw sąsiadujących z Rosją wobec jej działań (Kendall, 2008).

W związku z przebiegiem i skutkami konfliktu gruzińsko-rosyjskiego z 2008 roku zmiana strategii rosyjskiej ekspansji wydaje się zrozumiała.

5 Jednocześnie obserwatorzy konfliktu wskazują, że choć Gruzini faktycznie zaatakowali, wynikało to z prowokacji, zaś działanie Rosjan było niezgodne z prawem międzynarodowym (Laaneots, Ühendatud, 2016, s. 21). 
Wojna w Donbasie jest realizacją takiej samej ekspansyjnej polityki, opierającej się na wspieraniu prorosyjskich separatystów przez działania propagandowe oraz zaopatrywanie ich w sprzęt i żołnierzy, jednak tym razem bez otwartej deklaracji swojego udziału. Jednak, mimo iż udział Rosji w tym konflikcie jest niepodważalny, nie spotkał się z (kontr)interwencją ze strony innych państw (Kernot, 2015, s. 127). Sugeruje to, że taka zmiana sposobu działania przyniosła korzyść Rosji, a więc może stać się sposobem na prowadzenie bezpiecznej ekspansji w przyszłości. Dodatkowo, wydaje się, że z uwagi na rozbudowany system sojuszy i układów międzynarodowych, które obecnie wiążą państwa na świecie, taki sposób prowadzenia wojen może stać się w przyszłości głównym zagrożeniem dla pokoju. Można się bowiem spodziewać, że w większości przypadków otwarte wypowiedzenie wojny, nawet „sprawiedliwej”, spotkałoby się z eskalacją konfliktu na światową skalę. Wojny światowe zaś, z uwagi na wspomnienie terroru i ogromnych kosztów wszystkich stron zaangażowanych w takie konflikty, wydają się nieopłacalne, zarówno dla obrońców jak i atakujących, a ich wizja działa na zasadzie analogicznej do odstraszania nuklearnego. Komentatorzy NATO wydają się to potwierdzać, gdyż wskazują, że między innymi właśnie wydarzenia na Ukrainie pokazują, że rozbudowane systemy sojuszy nie są już wystarczającym zabezpieczeniem przed inicjowaniem konfliktów zbrojnych (Grand, 2016).

\section{Podsumowanie - problem secesji na rzecz istniejącego państwa}

Wydarzenia w Gruzji i na Ukrainie świadczą o tym, że secesja na rzecz istniejącego państwa stanowi lukę zarówno w teorii wojny sprawiedliwej, jak i w postanowieniach paktów i systemu sojuszy międzynarodowych, dzięki której silne państwa mogą realizować politykę ekspansyjną i poszerzać swoje granice kosztem słabszych sąsiadów.

Porównanie długości wojny w Osetii Południowej z wojną w Donbasie pokazuje, że nieprowokujący do światowej reakcji charakter konfliktu, może być groźniejszy od jawnej inwazji: podczas gdy walki w Gruzji trwały pięć dni, wojna w Donbasie wciąż trwa, już od ponad sześciu lat. Jest ona jednocześnie wojną nietypową - wymykającą się ramom teoretycznym i typową, gdyż jest kolejnym konfliktem tego rodzaju oraz jedynym aktualnie 
prowadzonym i najdłużej trwającym konfliktem zbrojnym w Europie po II wojnie światowej. Jest to wojna bezpieczna dla świata, gdyż nie prowadzi do masowej eskalacji konfliktu, ale też niszczycielska dla stron walczących, które systematycznie, nawet w okresach zawieszenia broni i zamrożenia konfliktu, stale ponoszą straty w ludziach, a terytorium, którego dotyczy konflikt zamiast rozwijać się i prosperować popada w ruinę.

Wydaje się, że właśnie z uwagi na to, obecna teoria wojny sprawiedliwej i rozważania na temat etyki wojny muszą zostać uzupełnione. Należy odpowiedzieć na potrzeby zrozumienia konfliktu opartego na secesji na rzecz istniejących państw i przeciwdziałać wykorzystywaniu go do ekspansji przez światowe mocarstwa.W przeciwnym wypadku, mimo oficjalnego wypierania się ekspansjonizmu, kolejne mocarstwa będą niemo wygłaszać dialog melijski i bez słowa realizować politykę zaprezentowaną w mowie Ateńczyków.

\section{MGR PAWEŁ NEUMANN-KARPIŃSKI}

Instytut Historyczny

Uniwersytet Szczeciński

ul. Krakowska 71/79, 71-017 Szczecin

karpinski.pawel17@gmail.com

\section{Bibliografia}

Fabre, C. (2016). Cosmopolitan Peace. Oxford: Oxford University Press.

Finlay, Ch.J. (2015). Terrorism and the Right to Resist: A Theory of Just Revolutionary War. Cambridge: Cambridge University Press.

Kernot, E. (red.). (2015). The war in Ukraine: lessons for Europe. Riga: The Centre for East European Policy Studies, University of Latvia Press.

Laaneots, A., Ühendatud K. (2016). The Russian-Georgian War Of 2008: Causes And Implication. Estonian National Defence College.

McMahan, J. (2009). Etyka zabijania na wojnie. W: T. Kuniński, T. Żuradzki (red.). Etyka wojny. Antologia tekstów. Warszawa: Wydawnictwo Naukowe PWN.

Tukidydes (1998). Wojna Peloponeska. Warszawa: Czytelnik.

Walzer, M. (2010). Wojny sprawiedliwe i niesprawiedliwe. Rozważania natury moralnej z uwzględnieniem przykładów historycznych (tłum. M. Szczubiałka). Warszawa: Wydawnictwo Naukowe PWN. 


\section{Źródła cyfrowe i artykuły prasowe}

BBC (2014a, 25 sierpnia). Ukraine crisis: 'Column from Russia'crosses border. BBC News.

Pobrane z: https://bbc.com/news/world-europe-28924945.

BBC (2014b, 5 września). Ukraine and pro-Russia rebels sign ceasefire deal. BBC News. Pobrane z: https://www.bbc.com/news/world-europe-29082574. BBC (2014c, 26.08). Captured Russian troops 'in Ukraine by accident'. BBC News. Pobrane z: https://bbc. com/news/world-europe-28934213.

Borger, J. (2015, 11 maraca). Russian military shelled Ukraine from mid-July, report says. The Guardian. Pobrane $\mathrm{z}$ : theguardian.com/world/2015/mar/11/ russia-struggling-ukraine-military-operations-report.

D’Agata, Ch. (2014, 6 marca). Ukrainian city of Donetsk epitomizes country's crisis. CBS News. Pobrane z: https://www.cbsnews.com/news/ukrainian-city-of-donetsk -epitomizes-countrys-crisis/.

Gazeta.pl (2014, 24 maja). MSW: Już 17 tys. milicjantów po stronie separatystów; Merkel $i$ Hollande dzwonia do Putina ws. ukraińskich wyborów [PODSUMOWANIE DNIA]. Wiadomości.Gazeta.pl. Pobrane z: http://wiadomosci.gazeta.pl/wiadomosci/1,114871,16027803,MSW_Juz_17_tys_milicjantow_po_stronie_separatystow_html.

Gordon, M.R. (2014, 22 sierpnia). Russia Moves Artillery Units Into Ukraine, NATO Says. New York Times. Pobrane z: nytimes.com/2014/08/23/world/europe/russia-moves-artillery-units-into-ukraine-nato-says.html.

Grand, C. (2016, 4 lipca). Nuclear deterrence and the Alliance in the 21st century. NATO Review. Pobrane z: https://www.nato.int/docu/review/articles/2016/07/04/nuclear-deterrence-and-the-alliance-in-the-21st-century/index.html.

Grove, T., Strobel, W. (2014, 29 lipca). Special Report: Where Ukraine's separatists get their weapons. Reuters. Pobrane z: https://reuters.com/article/us-ukraine-crisis-arms-specialreport/special-report-where-ukraines-separatists-get-their-weapons-idUSKBN0FY0UA20140729? feedType $=$ RSS\&feedName $=$ worldNews.

Grytsenko, O. (2014, 12 kwietnia). Armed pro-Russian insurgents in Luhansk say they are ready for police raid. KyivPost. Pobrane z: https://web.archive.org/ web/20140412131249/http://www.kyivpost.com/content/ukraine/armed-pro-russian-insurgents-in-luhansk-say-they-are-ready-for-police-raid-343167.html.

Harding, L., Walker, S. (2014, 17 marca) Crimea applies to be part of Russian Federation after vote to leave Ukraine. Guardian.com. Pobrane z: https://www.theguardian.com/ world/2014/mar/17/ukraine-crimea-russia-referendum-complain-result.

Interfax-Ukraine (2014, 18 marca). Law enforcers collect evidence of Russian services' involvement in unrest in eastern Ukraine - Yatseniuk. Interfax.com.ua. Pobrane z: https://en.interfax.com.ua/news/general/196506.html.

Kendall, B. (2008, 21 sierpnia). Russia's neighbours go their own way. BBC News. Pobrane z: http://news.bbc.co.uk/2/hi/europe/7575813.stm.

Kramer, A.E., Gordon, M.R. (2014, 27 sierpnia). Ukraine Reports Russian Invasion on a New Front. New York Times. Pobrane z: nytimes.com/2014/08/28/world/europe/ ukraine-russia-novoazovsk-crimea.html.

Kushch, L. (2014, 16 marca) Pro-Russian demonstrators burn books, storm buildings in eastern Ukraine. Reuters.com Pobrane z: https://web.archive.org/ 
web/20140316215525/https://www.reuters.com/article/2014/03/16/us-ukraine-east-idUSBREA2F0P 220140316.

North, A. (2015, 14 lipca). Georgia accuses Russia of violating international law over South Ossetia. The Guardian. Pobrane z: https://www.theguardian.com/world/2015/jul/14/ georgia-accuses-russia-of-violating-international-law-over-south-ossetia.

RFE/RL (2018, 11 sierpnia). Monitor Posts Video Of Truck Convoys Between Russia, Eastern Ukraine. Radio Free Europe/Radio Liberty. Pobrane z: https://www.rferl. org/a/osce-monitor-publishes-video-truck-convosy-between-russia-ukraine-first-evidence-illegal-crossings/29427195.html.

Sutyagin, I. (2015, 9 marca), Russian Forces in Ukraine, Rusi.org. Pobrane z: https://rusi. org/publication/briefing-papers/russian-forces-ukraine.

TASS (2014, 16 kwietnia). Russia blasts US assessment of events in Ukraine's southeast. TASS Russian News Agency. Pobrane z: http://tass.ru/en/russia/728304.

Tsvetkova, M. (2015, 21 lipca). Ceasefire brings limited respite for east Ukrainians. Reuters. Pobrane z: https://web.archive.org/web/20150725132924/http://www.euronews. com/newswires/3041823-ceasefire-brings-limited-respite-for-east-ukrainians/.

Tsvetkova, M., Osborn, A. (2015, 17 grudnia). Russia's Putin lashes Turkey, says Russian forces were in Ukraine. Reuters. Pobrane z: https://uk.reuters.com/article/ uk-russia-putin-idUKKBN0U01KP20151217.

TVN24 (2014, 15 kwietnia). Specnaz w Doniecku? Gubernator: Nie ukrywali dystynkcji, ich rozmowy styszeli mieszkańcy. TVN24 Biznes i Świat. Pobrane z: https://www. tvn24.pl/wiadomosci-ze-swiata,2/specnaz-w-doniecku-gubernator-nie-ukrywali-dystynkcji-ich-rozmowy-slyszeli-mieszkancy,418659.html.

Wirtualna Polska. (2014, 14 marca). Krym i Sewastopol uznane za części FR z chwila podpisania traktatu. Wp.pl. Pobrane z: https://wiadomosci.wp.pl/krym-i-sewastopol-uznane-za-czesci-fr-z-chwila-podpisania-traktatu-6031307004600961a.

Zinets, N., Madorsky, D. (2014, 22 sierpnia). Ukraine accuses Russia of invasion after aid convoy crosses border. Reuters. Pobrane z: https://web.archive. org/web/20140822150641/https://www.reuters.com/article/2014/08/22/ us-ukraine-crisis-aid-convoy-idUSKBNOGMOIS20140822. 